\title{
Sulfide removal using immobilized living cell in alginate matrices in anaerobic condition
}

\author{
Okti Dinasakti Nurul Mentari ${ }^{1}$, Qomarudin Helmy ${ }^{1,2}$, and Edwan Kardena ${ }^{1,2,3^{*}}$ \\ ${ }^{1}$ Environmental Engineering Dept, ITB, Bandung, Indonesia \\ ${ }^{2}$ Water and wastewater Engineering Research Group, ITB, Bandung, Indonesia \\ ${ }^{3}$ Bioscience and Biotechnology Research Center, ITB, Bandung, Indonesia
}

\begin{abstract}
Biological sulfide oxidation using immobilized cells offers high removal efficiency, minimum cell loss, possibility of cells reuse, and protect cells from harmful substances and conditions in the bulk environment. In this study, sulfide was treated using immobilized cells under anaerobic batch process. Two methods of immobilization used in the process: using sodium alginate (AL) and chitosan-covered sodium alginate (ALC). Chitosan addition is expected to give better mechanical properties to the alginate matrix. Microbial culture used in the study was obtained from the Cikapundung river's sediment. This experiment showed that the sulfide removal process using AL and ALC matrices achieved $93 \%$ and $98 \%$ removal after 10 days of incubation period, respectively.
\end{abstract}

\section{Introduction}

Sulfide is a compound produced from the sulfur reduction process under anaerobic conditions, which is toxic to humans and living things if they are it is exposed to high concentrations. Sulfide removal using a biological process has become a preferred choice since its low-cost efficiency, high removal ability, and also does not generate hazardous waste by-product after process.

Biological treatment for sulfide compounds has been carried out since 1987 using sulfur-oxidizing bacteria (SOB) [1]. Recent studies about biological sulfide oxidation mainly talked about sulfide removal using immobilized cells. Biological treatment using immobilized cells offers some advantages which is not available in the suspended systems, such as higher cell density, higher activity and higher endurance towards toxic substances [2]. In the treatment process of wastewater containing high sulfide concentration, sulfide is utilized as a substrate by the SOB, yet it also gives an adverse impact on the cells because of its toxicity. Therefore, SOB activities in oxidizing sulfur reduced compounds will be inhibited. By using the immobilization technique, cells will become protected from the bulk liquid so it will less affected by the toxic environmental conditions. [3].

Another advantage of sulfide removal using immobilization techniques is to reduce the release of biomass from the reactor due to waste disposal in the treatment process using suspended cells. Previous research regarding biological sulfide oxidation has been done using Thiobacillus sp. immobilized in various matrices. From the study, it was obtained that satisfactory results for biological sulfide oxidation as well as reducing cell release from the system using immobilization in the calcium alginate matrix [4].

Alginate is a natural anionic polymer, extracted from brown algae and can be formed into a gel or microparticles. The gelation process is usually done by adding alginate solution into a cationic solution like $\mathrm{CaCl}_{2}$ with a certain concentration. Moreover, alginate also can be reacted with cationic polymer. One of the common polymer added to the alginate is chitosan. Chitosan is a polysaccharide obtained from chitin shells of crustacean including shrimp and crab. Chitosan addition to the alginate creates polyelectrolyte complex between their interface. The formed complex is believed to improve the beads stability [5].

In this research, sulfide oxidation was done using microbial culture immobilized in sodium alginate (AL) and chitosan-covered alginate beads (ALC) in batch process under limited oxygen condition.

\section{Materials and methods}

\subsection{Microorganism}

Microorganism in this study was obtained from Cikapundung river's sediments. Sulfur oxidizing bacteria existence in the sediment was discovered using winogradsky column. After incubation for one month, the gradient of the column was observed. The column showed three color zones: yellowish zone, purplish zone and green zone. The zones were expected to be the existence indicator of iron-oxidizing bacteria, purple sulfur bacteria and green sulfur bacteria. These bacteria later were cultivated and used for the immobilization process.

* Corresponding author: kardena@pusat.itb.ac.id 


\subsection{Organism cultivation}

Mixed SOB cultures from Cikapundung river's sediment grown with glucose as a substrate in an anaerobic batch reactor (approximately, $6 \mathrm{~g} / \mathrm{L}$ dry weight cell) were harvested by centrifugation ( $2900 \mathrm{xg}$ for $10 \mathrm{~min})$ and then washed with distilled water.

\subsection{Preparation of immobilized cells}

\subsubsection{Preparation of immobilization using alginate beads}

$4 \%(\mathrm{w} / \mathrm{v})$ sodium alginate was dissolved in distilled water, autoclaved $\left(121^{\circ} \mathrm{C}, 20 \mathrm{~min}\right)$, added with mixed SOB culture in a beaker, shaken mildly. $\mathrm{A} \mathrm{CaCl}_{2}$ solution $4 \%$ $(\mathrm{w} / \mathrm{v})$ was prepared in a separated beaker. The mixture containing the cells and sodium alginate was added dropwise to $\mathrm{CaCl}_{2}$ solution using a syringe and immediately forming $3 \mathrm{~mm}$-diameter beads. The beads were hardened in the solution for $1 \mathrm{~h}$. After hardening, the beads were rinsed with distilled water and ready to be used for sulfide removal experiments.

\subsubsection{Preparation of immobilization using chitosan- covered alginate beads (ALC)}

The following immobilization method using chitosancovered alginate beads was adapted and modified from the previous study conducted by Duarte [6]. 4\% (w/v) sodium alginate was dissolved in distilled water, autoclaved $\left(121^{\circ} \mathrm{C}, 20 \mathrm{~min}\right)$, added with mixed SOB culture in a beaker, mixed mildly. $\mathrm{A} \mathrm{CaCl}_{2}$ solution $4 \%$ $(\mathrm{w} / \mathrm{v})$ was prepared in a separated beaker. In another beaker, a chitosan solution $0.25 \%(\mathrm{w} / \mathrm{v})$ diluted in $5 \%$ acetic acid was prepared. The mixture containing the cells and sodium alginate was added dropwise to $\mathrm{CaCl}_{2}$ solution using a syringe and immediately forming $3 \mathrm{~mm}$ diameter beads. The beads were hardened in the solution for $1 \mathrm{~h}$. After hardening, the beads were rinsed with distilled water and then added to the chitosan solution and shaken for 1 hour. The beads were then rinsed with distilled water.

\subsection{Sulfide solution preparation}

Reagent water was prepared by degassing distilled water with nitrogen gas for 15 to 30 minutes. Sulfide solution was prepared by dissolving 3.75 gram sodium sulfide $\left(\mathrm{Na}_{2} \mathrm{~S} \cdot 9 \mathrm{H}_{2} \mathrm{O}\right)$ crystals into a reagent water and bring the final volume to $500 \mathrm{~mL}$. This will give a stock solution which $1 \mathrm{~mL}=1 \mathrm{mg} \mathrm{S}^{2-}$. The stock then standardized using the iodometric method (SMEWW $4500 \mathrm{~S}^{2-} \mathrm{F}$ ). The stock solution then diluted to several concentrations $(0.2 \mathrm{mM}$, $0.4 \mathrm{mM}, 0.6 \mathrm{mM}, 0.8 \mathrm{mM}$, and $1.0 \mathrm{mM}$ ), flushed with nitrogen gas to ensure the dissolved oxygen content within the solution would be approximately between the range of 0 to $0.3 \mathrm{mM}$ and used for sulfide removal experiments.

\subsection{Batch removal experiments using the immobilized cells}

Approximately $10 \mathrm{~g}$ of immobilized beads were added into $0.5 \mathrm{~L}$ Erlenmeyer flask containing $0.5 \mathrm{~L}$ of sulfide solution. All the flasks were sealed with rubber cap modified with gooseneck, placed in room temperature without shaking. Samples were collected every $24 \mathrm{~h}$ for 10 days.

\subsection{Analytical methods}

Sulfide concentration was determined using methylene blue method from SMWW 4500 D. Sulfate concentration as the oxidation product was determined using turbidimetry methods. Dissolved oxygen within the sulfide solution was measured using DO mater (Lutron) and $\mathrm{pH}$ was measured using $\mathrm{pH}$ meter (Hanna Instrument).

\subsection{Scanning electron microscope (SEM)}

The immobilized cell beads were washed three times using a phosphate buffer. Then, the sample was soaked with gradually increasing ethanol concentrations (30\%, $50 \%, 70 \%, 80 \%, 90 \%, 95 \%$, and $100 \%$ ) for approximately 15 minutes at every process. To remove excess water inside the matrix, the samples were freezedried for 18 hours. The dried beads then coated with gold and analyzed for SEM.

\section{Result and discussion}

\subsection{Sulfite removal and sulfate production of $A L$ and ALC beads}

The experiments were carried out in the anaerobic reactor without the addition of another dissolved oxygen compound; to see the ability of the microorganisms under limited oxygen conditions. The matrices used in the experiment included alginate (AL) matrices and chitosancovered alginate matrices (ALC). A decrease of sulfide usually occurs by abiotic oxidation of sulfide or the transformation of liquid sulfide to the gas phase. It was minimized within the system by flushing the reactor using nitrogen gas at the beginning of the experiment.

The results of sulfide removal with the initial concentrations of $0.2,0.4,0.6,0.8$ and $1.0 \mathrm{mM}$ using two methods of alginate immobilization can be seen in Fig. 1 . The sulfide concentration of $0.2 \mathrm{mM}$ was reached negligible value within 2 days. Biological oxidation of sulfide can be occur through some reactions in Eq. 1 and Eq. 2.

$$
\begin{aligned}
& \mathrm{HS}^{-}+2 \mathrm{O}_{2} \rightarrow \mathrm{SO}_{4}{ }^{2-}+\mathrm{H}^{+} \\
& \mathrm{HS}^{-}+0.5 \mathrm{O}_{2} \rightarrow \mathrm{S}^{0}+\mathrm{OH}^{-}
\end{aligned}
$$



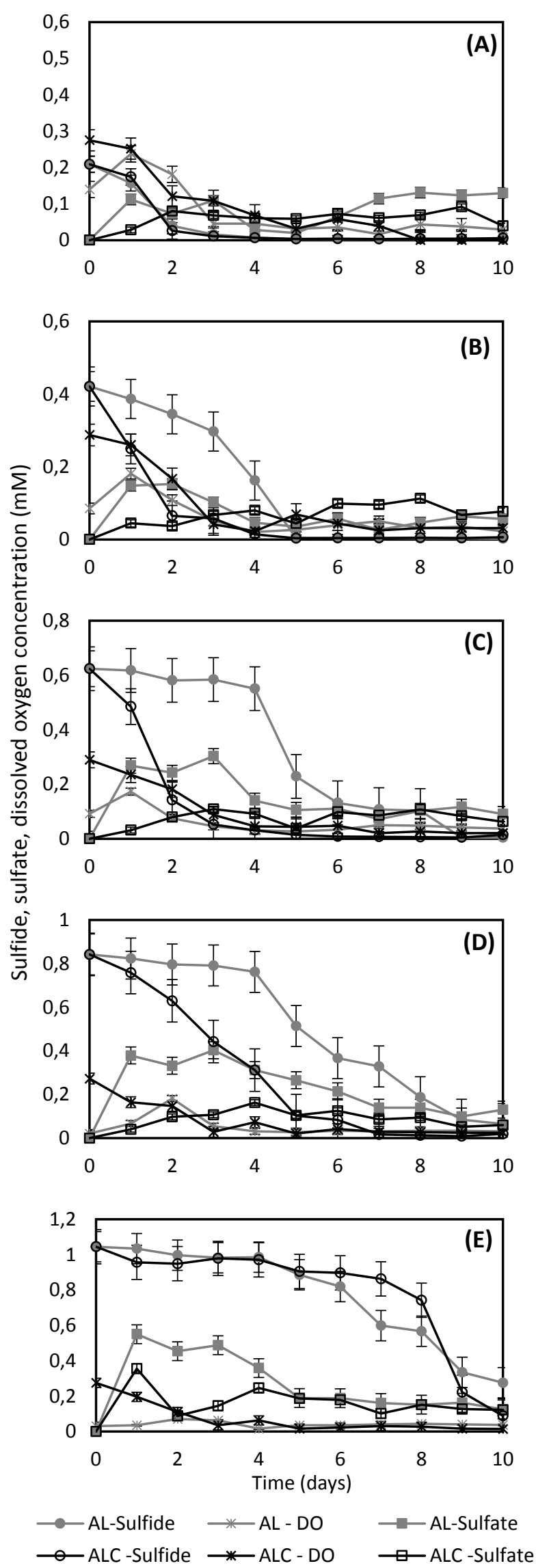

Fig 1. Profiles of sulfide and sulfate of immobilized cells in AL and ALC matrices with various initial sulfide concentration: (A) 0.2 (B) 0.4, (C) 0.6, (D) 0.8, and (E) 1,0 mM.
The stoichiometry of reaction (1) indicates that oxidation of each mole of sulfide would result in one mole of sulfate or one mole of sulfur, depending on the oxygen availability. From Fig. 1, it can be seen that that generally sulfate production will increase along with the removal of sulfide but then decreased. The decrease of sulfate concentration likely due to the system which ran out of oxygen, resulting in an anaerobic condition in which oxygen can not be the electron acceptor and replaced by sulfate. The sulfate reduction process was helped by the Sulfate Reducing Bacteria (SRB) which contains in the immobilized mixed culture. It was observed that there was no increase of sulfide concentrations while the sulfate decrease. This indicated that sulfate reduced into another form of the reduced sulfur compound such as adenosine phosphosulfate (APS) or sulfite through dissimilatory or assimilatory sulfate reduction [7].

\subsection{Immobilized cells bead morphology characteristics}

In the experiment of sulfide removal using immobilized cells in AL and ALC matrices, the matrices color changed from the original color (reddish-brown) into black which can be seen in Fig.2. The color change was caused by iron sulfide oxidation reaction (mainly pyrite and pyrotite) which led to acidic conditions. Pyrite oxidation generally occurs in two steps, the first step is pyrite oxidation into ferrous iron $\left(\mathrm{Fe}^{2+}\right)$ explained in Eq.3. When further oxidation happens, ferrous iron later will be oxidized into ferric iron $\left(\mathrm{Fe}^{3+}\right)$ in Eq.4.

$$
\begin{aligned}
& \mathrm{FeS}_{2}+3.5 \mathrm{O}_{2}+\mathrm{H}_{2} \mathrm{O} \leftrightarrow \mathrm{Fe}^{2+}+2 \mathrm{SO}_{4}{ }^{2-}+2 \mathrm{H}^{+} \\
& 14 \mathrm{Fe}^{2+}+3.5 \mathrm{O}_{2}+14 \mathrm{H}^{+} \leftrightarrow 14 \mathrm{Fe}^{3+}+7 \mathrm{H}_{2} \mathrm{O}
\end{aligned}
$$

However, the matrices did not change color in sulfide removal experiment using ALC matrices in the concentrations of $0.2 \mathrm{mM}$ and $0.4 \mathrm{mM}$ because there was a reaction between sulfide with acetic acid contained in ALC matrices, resulting in a transformation of dissolved sulfide into gas phase sulfide $\left(\mathrm{H}_{2} \mathrm{~S}\right)$ in Eq.5.

$$
\mathrm{HS}^{-}+2 \mathrm{CH}_{3} \mathrm{COOH} \rightarrow \mathrm{H}_{2} \mathrm{~S}+\mathrm{CH}_{3} \mathrm{COO}^{-}
$$

The formation of hydrogen sulfide during the experiment using ALC matrices was observed through lead acetate paper. The color of the paper changed from white into black when it reacted with hydrogen sulfide
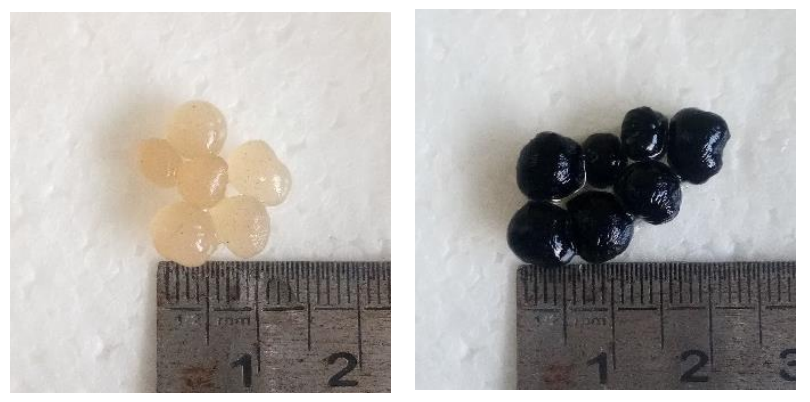

Fig 2. Color change of immobilized cells beads during sulfide removal experiment process:(Left) Before, (Right) After. 


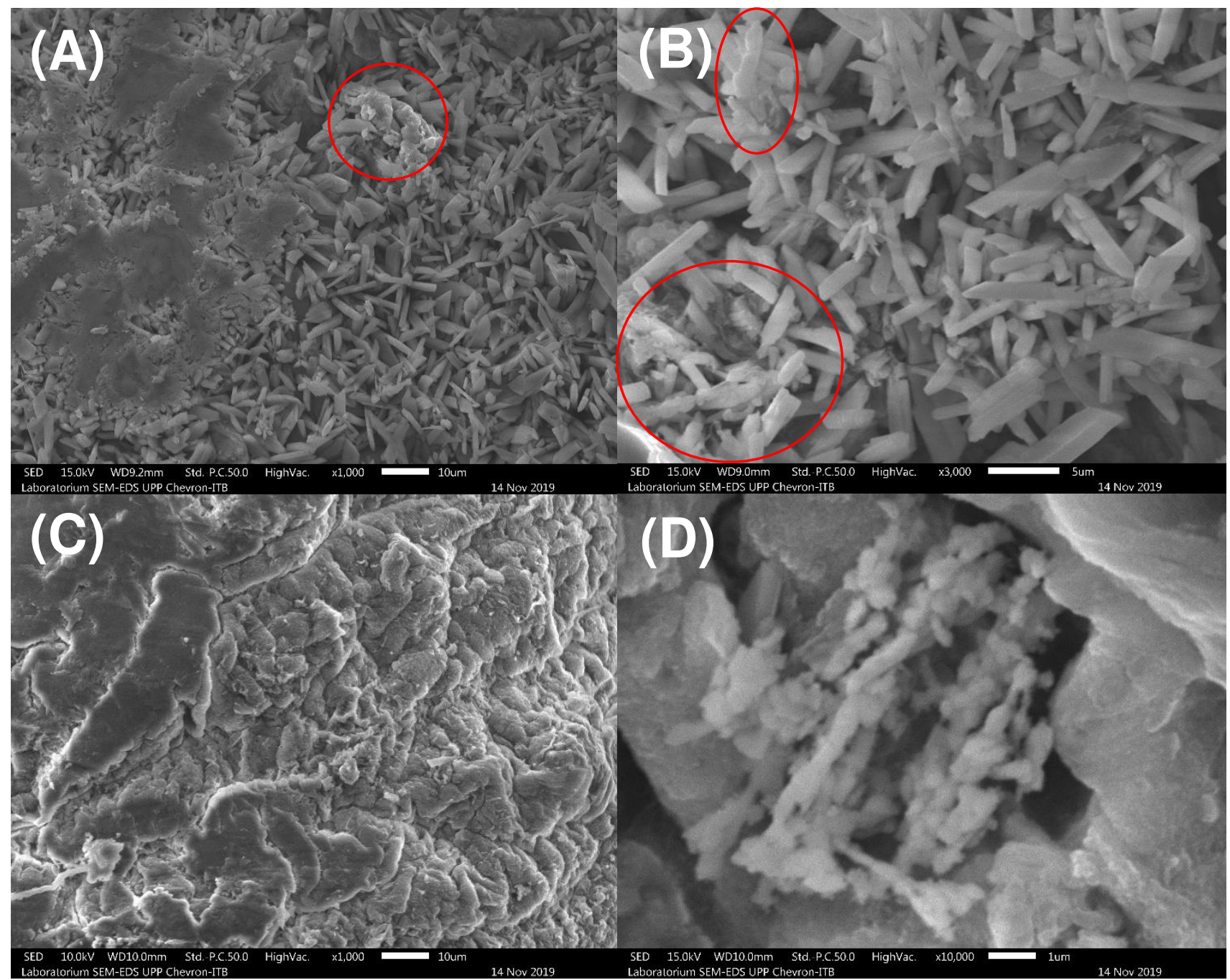

Fig 3. Representative of SEM images of immobilized cells within: (A) surface of AL matrix (1000× magnification), (B) cross section of AL matrix (3000× magnification), (C) surface of ALC matrix (1000× magnification), (D) cross section of ALC (10000× magnification)

gas. It was also noticed that the addition of ALC matrices into sulfide produced rotten egg odor in the early days of the sample measurement process. The data in Fig.1 also shows that the ALC matrices produced less sulfate (almost negligible) compared to the $\mathrm{AL}$ matrices, indicating that the dissolved sulfide compound in water was volatilized into hydrogen sulfide gas upon reaction with acetic acid in the ALC matrices.

The bead morphology can be shown through SEM interpretation in Fig 3. In Fig 3A and 3B, alginate has a
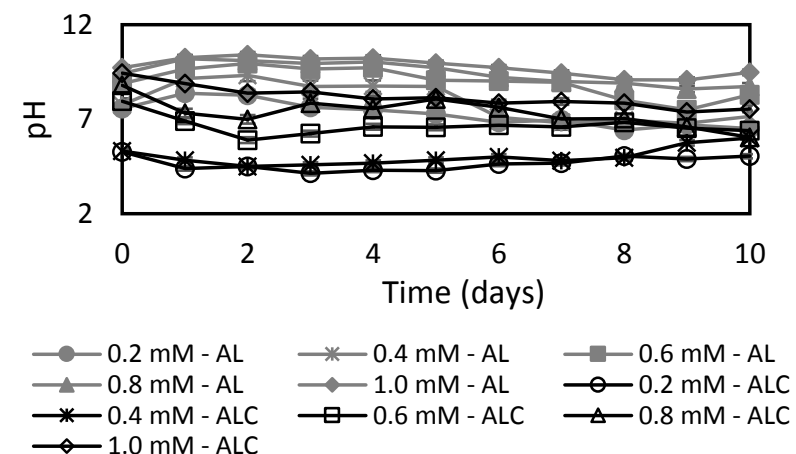

Fig. 4. Sulfide $\mathrm{pH}$ during removal experiment using AL and ALC matrices within various initial concentration $(0.2,0.4,0.6,0.8$, and $1.0 \mathrm{mM}$ ) hexagonal-like-shape and the number of bacteria can be seen attached between the AL matrix shown by the red circle. While in Fig 3C, the surface of the ALC matrix was covered by chitosan layer, giving the cells more adherence to the bead surface. Chitosan also created a smoother exterior to the ALC outer surface, resulting in a decrease of the bead porosity. The appearance of the cells within the ALC matrix that can be observed in Fig 3D. The cells were dominated with rod-shaped bacteria but some of the oval-shaped bacteria also can be noticed in the figure. It was also visible that the cells were attached to one another within the pores of the ALC matrix.

\subsection{Acidification during sulfide removal experiment}

During the sulfide removal experiment, it was observed from Fig. 4 that sulfide $\mathrm{pH}$ in AL matrices did not change significantly meanwhile in ALC matrices, the initial $\mathrm{pH}$ dropped from basic to acidic condition before going stable afterward. The $\mathrm{pH}$ decreased in ALC matrix was due to the recess of acetic acid within the matrix that did not react with $\mathrm{HS}^{-}$while $\mathrm{HS}^{-}$in aqueous phase was already run out from reaction with $\mathrm{H}^{+}$, transforming sulfide into the gas 


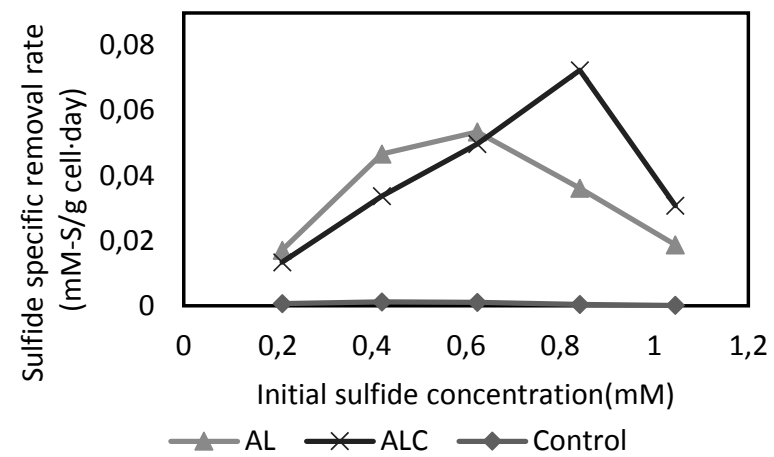

Fig. 5. Effect of initial sulfide concentration on specific sulfide removal

phase $\mathrm{H}_{2} \mathrm{~S}$ and $\mathrm{H}^{+}$formation will make the solution become acidic.

Aside from the alter of the $\mathrm{pH}$ in sulfide aqueous phase caused by $\mathrm{H}^{+}$released from acetic acid in the ALC experiment, acidification in sulfide removal process often occurs naturally when sulfate is produced by chemolithotropic bacteria with sufficient supply of oxygen [8]. Over the experiment using AL matrix, the conversion of sulfide into sulfate occured between the range of $20-50 \%$, from various initial sulfide concentrations $(0.2-1.0 \mathrm{mM})$. Based on data, it was obtained that AL matrix could oxidize $0.2 \mathrm{mM}$ sulfide with the removal rate of $0.103 \mathrm{mM} /$ day and produced sulfate with $0.014 \mathrm{mM} /$ day. The trend of the stable $\mathrm{pH}$ and low sulfate production explained that the product of sulfide oxidation in the experiment mainly was sulfur or another sulfide oxidized form [9].

\subsection{Effects of sulfide concentration}

The effect of sulfide concentrations on its removal by the immobilized cells in AL and ALC matrices was investigated by feeding various concentrations of sulfide $(0.2,0.4,0.6,0.8$, and $1.0 \mathrm{mM})$ under the following conditions: $6 \mathrm{~g} / \mathrm{L}$ cells and 10 gram matrix within $500 \mathrm{ml}$ sulfide. Fig. 5 Shows that the sulfide removal rate in AL matrix decrease when the initial sulfide concentration exceeds $0.6 \mathrm{mM}$, while in ALC matrix similar results occured at $0.8 \mathrm{mM}$.

The higher removal rate in ALC matrix is influenced by the reduction of $\mathrm{HS}^{-}$to $\mathrm{H}_{2} \mathrm{~S}$ in its reaction with acetic acid and obtaining $\mathrm{H}^{+}$, resulting half of the dissolved sulfide turning into a gas andreleasing the smell of rotten eggs. The decrease in the sulfide removal rate was likely due to inhibition from sulfide as a substrate which also has toxic effects for microorganisms at a certain level [10]. Therefore, the bacteria need a longer time to adapt with a higher concentration of sulfide before utilizing it as a substrate and undergoing sulfide oxidation biologically.

\section{Conclusion}

ALC matrix showed higher sulfide removal than AL matrix, yet the removal was effected by the reaction between sulfide (HS-) with acetic acid, resulting in a transformation of sulfide into its gas phase. From the SEM interpretation, it was observed that the chitosan layer acted as a barrier for the cells and reduced the porosity of the matrix. From the experiments, it was known that AL and ALC matrix could achieved removal efficiency of $93 \%$ and $98 \%$ after 10 days incubation period, respectively.

\section{Acknowledgments}

This study was supported by P3MI ITB research grant 2019.

\section{References}

[1] K. L. Sublette and N. D. Sylvester, "Oxidation of Hydrogen Sulfide by Thiobacillus denitrificans: Desulfurization of Natural Gas," Biotechnol. Bioeng., vol. XXIX, pp. 249-257, 1987.

[2] E. Kardena, S. L. Ridhati, and Q. Helmy, "Molecular imprinted hydrogel polymer ( MIHP ) as microbial immobilization media in artificial produced water treatment Molecular imprinted hydrogel polymer ( MIHP ) as microbial immobilization media in artificial produced water treatment," 2018.

[3] K. L. Sublette, "Immobilization of Thiobacillus Denitrificans for the oxidation of hydrogen sulfide in sour water," Appl. Biochem. Biotechnol., vol. 20-21, no. 1, pp. 675-686, 1989.

[4] P. Ravichandra, M. Gopal, and J. Annapurna, "Biological sulfide oxidation using autotrophic Thiobacillus sp.: Evaluation of different immobilization methods and bioreactors," $J$. Appl. Microbiol., vol. 106, no. 4, pp. 1280-1291, 2009.

[5] J. P. Paques, E. Van Der Linden, C. J. M. Van Rijn, and L. M. C. Sagis, "Preparation methods of alginate nanoparticles," Adv. Colloid Interface Sci., vol. 209, pp. 163-171, 2014.

[6] J. C. Duarte, J. A. R. Rodrigues, P. J. S. Moran, G. P. Valença, and J. R. Nunhez, "Effect of immobilized cells in calcium alginate beads in alcoholic fermentation," pp. 1-8, 2013.

[7] M. B. Goldhaber, "Sulfur-rich Sediments," in Treatise in Geochemistry, Elsevier Ltd, 2003, pp. 257-288.

[8] D. Pokorna and J. Zabranska, "Sulfur-oxidizing bacteria in environmental technology," Biotechnol. Adv., vol. 33, no. 6, pp. 1246-1259, 2015.

[9] N. Hou, Y. Xia, X. Wang, H. Liu, and H. Liu, "H $2 \mathrm{~S}$ biotreatment with sulfide-oxidizing heterotrophic bacteria," Biodegradation, vol. 6, 2018.

[10] W. Kuo and T. Shu, "Biological pre-treatment of wastewater containing sulfate using anaerobic immobilized cells," vol. 113, pp. 147-155, 2004. 